\title{
Cytotoxic prenylated xanthone and coumarin derivatives from Malaysian Mesua beccariana
}

\begin{abstract}
Our recent research on the phytochemical constituents of the stem bark of Mesua beccariana gave one new xanthone, beccarixanthone $\mathrm{T}$ (1) and one new coumarin, beccamarin $\mathrm{T}$ (2) together with three known xanthones mesuarianone (3), mesuasinone (4), 1,5dihydroxyxanthone (5) and four known terpenoids, friedelin (6), stigmasterol (7), betasitosterol (8) and gamma-sitosterol (9). The structures of these compounds were elucidated and determined using spectroscopic techniques such as NMR and MS. The cytotoxic activities of compounds 1-4 as well as the crude extracts were tested against two cancer cell lines, Hep G2 (liver cancer cell line) and HT-29 (colon cancer cell line) using MTT assays. Mesuarianone (3) gave a significant activity on the HT-29 cell line while mesuasinone (4) gave moderate activity against HT-29 cell line.
\end{abstract}

Keyword: Mesua beccariana; Coumarin; Xanthone; Cytotoxic 